\title{
Replik
}

\section{Af Kaj Thaning}

Årgang 1991 af Grundtvig-Studier giver mig anledning til en ny replik, da den rummer to angreb på min Grundtvigbog. Dem kan der være grund til at imødegå.

Først citerer Schjørring i sin nekrolog over Prenter dennes angreb. Da hans anmeldelse i sin tid blev trykt i Theologisk Tidsskrift, svarede jeg ham, men kun i et privat brev. Derfor nu nogle få bemærkninger.

Prenter påstår, at jeg sønderbrød forbindelsen mellem $1825 \mathrm{og}$ 1832, og han vilde ikke vide af, at der skulde være tale om en »omvendelse « $\mathrm{i}$ det sidstnævnte år. Han godkendte kun den almindelige kirkelige brug af det ord. Jeg mener, det kan bruges både om det at vende sig til Gud - og til hans værk, hvis man før har fornægtet det eller relativeret det, sådan som den lutherske bodskristendom fik Grundtvig til det, omend i større og efterhånden mindre grad. Selv Søndagsbogen III (1831) har mindelser derom. Så man forstår befrielsen i 1832. I det år var det i øvrigt mere bodskristendommen end romantikken (Prenter), der blev overvundet. At det skulde være opdagelsen af »Kirkens urokkelige kendsgerning «, der hjalp ham til at få »øje for livet « (Nordens Mythologi), har Prenter i hvert fald ikke sandsynliggjort.

I sin lange artikel om »Vejen fra tvang til frihed « hos Grundtvig protesterer William Michelsen mod min påstand, at der skulde være tale om en ændring i Grundtvigs livssyn i 1832. Han henholder sig til fortalen i Haandbog i Verdens-Historien I i 1833 (US VI s. 12), hvor Grundtvig erklærer, at han til skolebrug foretrækker den græske betragtning af menneskelivet og historien fremfor den »mosaisk-christelige«, som han før holdt sig til. Men nu er det altså det græske syn, der bedst lader sig »videnskabelig gennemføre «. Derimod siger han om den mosaiskkristelige anskuelse af livet: den »er mig nemlig, nu som før, den eneste guddommelig sande og eviggiældende «. Disse ord kunne synes at give Michelsen ret. Men jeg tror ikke, han har det. 
Ordet »Anskuelse« er året før rykket ind i Grundtvigs tankegang for at betegne en modsætning til den kristne tro. Grundtvig er på nye veje. Anskuelsen var dengang til videnskabeligt brug og fungerede, så længe han var på bibelsk grund. Men den duede ikke på græsk grund. Den var jo bibelsk. Derfor blev Grundtvig begejstret, da han mødte Polybs hedenske historiesyn. Han gik over til det. (Og det passede ham jo godt, at det byggede på modsætningen mellem sandhed og løgn.) Men nu var det selvfølgelig for svært for ham at operere med tre størrelser: et græsk historiesyn, en bibelsk anskuelse og så den kristne tro. Derfor smutter nu den bibelske anskuelse over på kirkens side og bliver det samme som troen (guddommelig sand og eviggældende). Det var anskuelsen ikke i 1832. Når den blev kaldt guddommelig, var det på grund af sine historiske virkninger. Men evig - nej. Det er den imidlertid nu blevet. På denne baggrund taler Grundtvig nu om modsætningen mellem kirke og skole, tro og vidskab, timeligt og evigt, hvor den mosaisk-kristelige anskuelse åbenbart er kommet over på kirkens, troens og evighedens side og derfor er uberettiget til at pånøde stat og skole en kirkelig skikkelse. Her må åbenbart det græske syn råde.

Men at Grundtvig har et ændret livssyn, fremgår da temmelig klart af det følgende begejstrede udbrud, hvor han taler om, »hvilken velsignet Ting det er, saaledes at slippe ud af det Tanke-Verdenens Chaos, hvori vi giennem mange Aarhundreder har befundet os «. Det kan da kaldes en omvendelse! Nu kan han »upartisk « tage »det stadige Hensyn paa Livet, som er Tidens Tarv.« Det er det, omvendelsen går ud på.

Jeg får altså det modsatte ud af den side, W.M. henviser til. Men i det hele taget er jeg jo uenig med hovedtanken i artiklen, der tolker Grundtvig som et bytte for påvirkning udefra, først forældrenes pres, så frigørelsen gennem Clara Bolton. Nej, tvangen rummedes $\mathrm{i}$ selve den lutherske bodskristendom, han $\mathrm{i}$ 1810 blev »chokeret ind i« (mit udtryk), og som i mindre og mindre grad holdt ham fangen indtil 1832, da befrielsen fra mange århundreders kaos kom.

Det er i hvert fald forkert, når Michelsen gætter på, at Clara Bolton skulde have overbevist Grundtvig om, at han burde indrømme Clausen den samme ret, han har krævet for sig selv: retten til at tænke frit. For Clausens fejl var jo netop den, at 
han som præstelærer $\mathrm{i}$ den kristne kirke pånødte de gammeldagstroende sine kætterier, uden at de kunne slippe for dem ved at forlade statskirken. Det er den ret, han ønsker, og som han beder Clausen anmode regeringen om, for at Clausen selv kan få fred for de gammeldags kristne. Ellers vil han åbenbart ikke kunne få det. Grundtvig har ikke givet ham ret til at tro som han vil!

Michelsen har altså misforstået slutningsordene $\mathrm{i}$ »Om den Clausenske Injuriesag« (US V s. 365) om at unde næsten samme ret, som man selv gør krav på. De rummer et krav til Clausen, ikke til Grundtvig.

I mange år har Grundtvig tumlet med tanker om religionsfrihed. Og så sent som i 1832 (Nordens Mythologi) kræver han en kirkelig skilsmisse. Først i »Om Daabs-Pagten« (1832) slår »den milde Lystanke« ham, at det vil være muligt at være $\mathrm{i}$ statskirken sammen, hvis blot sognebåndet bliver løst. Det er jo en helt ny tanke, efter at han først har villet have kirken renset for kættere, og derefter selv gå ud. Nu kan alle være i den, en tanke, der senere fører til, at kirken omdøbes til en borgerlig indretning (1834).

Grundtvig har været udenlands, og det præger hans frihedstanker. Han mener nu, at gejstlighedens lyst til at beherske troen ikke mindst må strande på »den Frihedsfølelse i aandelige Ting hos Individerne, der nu er langt anderledes herskende« end før (US V s. 373), og selv indser han, at »den størst muelige Frihed $\mathrm{i}$ aandelige Ting tjener os alle bedst «. Og skønt han kunne $\emptyset$ nske at være skilt fra sine kirkelige modstandere så skarpt som muligt, vil han gerne være dem så nær som muligt »for godt Landsmandsskabs Skyld«. Han har opdaget det folkeliges betydning. Det indvirker også på hans præstelige syn.

Friheden mellem mennesker må jo føre til, at den ene ikke trænger ind på den anden for troens skyld. Den er »hvert enkelt menneskes egen sag « (Menneske først s. 259f). Vi skal »lade andre beholde, bekjende og forplante deres Tro, ej ville pånøde dem vores« (sst. s. 518). Han erkender før at have stræbt »at påtvinge alle mennesker vor Tro...« (sst. s. 519). Hans nye syn kan samles i nogle ord fra 1837: "I den store Kamp for Livets Krone« må vi »have Lov til at søge ad hvilken Vej vi lyste, da det er noget vi alle trænge til, uden at nogen Fyrste er saa 
mægtig eller nogen Viis saa rig, at han kan give den til Næsten« (s. 266).

Der skal være kappestrid, ikke kamp i kirken. Kampen vil Grundtvig herefter føre kulturelt. Nordens Mythologi er kampråbet. Men den har også åbnet mulighed for, at naturalisten kan få ret kristeligt. Det ses ved tidernes ende. Men tanken om den bibelske anskuelse som fælles for »Folk med Aand «, bl.a. naturalisterne (Clausen), betyder, at Grundtvig kan tilbyde dem forlig og kulturelt samarbejde. Det er udtryk for et nyt livssyn hos Grundtvig og for det nye frihedssyn, der proklameres i tilegnelsesdigtet til Nordens Mythologi, som W.M. citerer, men som først er skrevet efter det vældige selvopgør, som fører til det trykte værk Nordens Mythologi, og som altså er et langt skridt på den anden side af det lille skrift mod Clausen fra 1831. 